\title{
Nieformalne miasta - wyzwania dla architektury społecznej
}

\section{Informal cities - challenges for the social architecture}

\section{Streszczenie}

Niniejszy artykuł prezentuje przykłady rozwiązań architektonicznych mających na celu pomoc w poprawie warunków życia w miastach nieformalnych powstających w Ameryce Południowej. Przedstawione projekty powstały na podstawie wyników światowych konkursów architektonicznych, analiz badań społecznych i kulturowych, konsultacji społecznych, czy też poprzez wprowadzenie radykalnych rozwiązań urbanistycznych do miast. Każdy z nich miał na celu zmniejszenie poziomu marginalizacji społecznej mieszkańców dzielnic biedoty oraz integrację części formalnej i nieformalnej miasta.

Słowa kluczowe: nieformalne miasta, slumsy, nieformalna urbanizacja, architektura socjalna, ubóstwo

\section{Abstract}

This article presents an overview of architectural solutions aimed at helping to improve living conditions in informal cities emerging in South America. The presented projects are based on the results of global architectural competitions, and based on the analysis of social and cultural research, social consultations and through the introduction of radical urban solutions. Each of these aims to reduce the level of social marginalisation of the residents of poor neighbourhoods and the integration of formal and informal parts of cities.

Keywords: informal cities, informal settlements, slums, social architecture, poverty 


\section{WSTĘP}

Problem miast nieformalnych dotyczy głównie krajów rozwijających się. Ze względu na klimat, problem powstawania i powiększania się dzielnic biedoty jest bardzo widoczny w wielu miastach państw położonych na półkuli południowej. Według danych z United Nations Human Settlements Programme (UN-Habitat) szacuje się, że około $1 \frac{1}{3}$ ludności w krajach rozwijających się mieszka w nieformalnych miastach. Statystyki na lata 2010-2022 pokazują, że slumsy rozrosną się o jeszcze 500 milionów mieszkańców, pomimo licznych programów pomocowych i innych pomysłów na rozwiązanie tego problemu ${ }^{1}$. Jedną z grup zajmujących się tym zagadnieniem są również architekci, podejmujący próby stworzenia domów socjalnych, które spowodują włączenie tych części nieformalnych do miasta formalnego. Tematyka ta jest o tyle skomplikowana, że nie wystarczy stworzyć dobrej jakościowo architektury, ale również bardzo ważne jest przeanalizowanie procesów społecznych prowadzących do ich powstawania, relacji pomiędzy formalnymi i nieformalnymi przestrzeniami miast czy występujących relacji pomiędzy miastami, równocześnie odnosząc wszystkie procesy do czynnika kulturowego.

\section{KWESTIE POJĘCIOWE}

Zanim będzie możliwe rozważenie sformułowanego problemu warto uzgodnić zakres znaczeniowy pojęć, którymi będę się posługiwać, tym bardziej iż nie są one w literaturze przedmiotu używane w sposób jednoznaczny. Poruszany przeze mnie problem dotyczy architektury rozważanej w kontekście ubóstwa. Pojęcie ubóstwa może być definiowane na różne sposoby, ale najczęściej bywa rozumiane jako zjawisko społeczno-ekonomiczne, którego istotą jest brak dostatecznych środków materialnych do zaspokajania potrzeb życiowych jednostki lub rodziny. Ministerstwo Rodziny, Pracy i Polityki Społecznej uznaje, że pojęcie to z jednej strony określa warunki życia jednostki, a z drugiej wskazuje na nierówności i sprzeczności występujące w społeczeństwie, równocześnie podkreślając wielowymiarowość tego zjawiska. W obszarze polityki społecznej ciągle podstawowe znaczenie mają informacje dotyczące zasięgu ubóstwa ekonomicznego².

Jedną z konsekwencji ubóstwa w sferze potrzeb mieszkaniowych jest w krajach rozwijających się powstawanie nieformalnych struktur miejskich, czyli slumsów. Pojęcie to jest ściśle związane z innymi określeniami, takimi jak nieformalna urbanizacja, migracja do miast czy też brak polityki mieszkaniowej ${ }^{3}$. Jedną z bardziej znanych definicji rozważanego zjawiska jest ta przytaczana przez United Nations, która określa gospodarstwa mieszkalne w slumsach jako grupę poszczególnych osób, zamieszkujących pod tym samym dachem bez dostępu do higieny sanitarnej, bieżącej wody, podstawowej infrastruktury i z ewidentnym brakiem miejsca do życia4 ${ }^{4}$ Można się też spotkać w literaturze przedmiotu z określeniem slumsów jako 
miast nieformalnych (informal cities, informal settelments). Justin McGuirk określa miasto nieformalne jako slumsy, równocześnie definiując, że

nie jest »ono" nieformalne dlatego, że nie posiada formy, ale z uwagi na to, że istnieja [one] poza prawnymi i ekonomicznymi protokołami kształtujqcymi miasto formalne. Nie oznacza to jednak, że slumsy sq chaotyczne. Może im brakować podstawowych miejskich usług, a jednak działajq w ramach własnych, samoregulujq̨cych się systemów, dajq̨c schronienie milionom ludzi w dobrze zintegrowanych społecznościach i oferujq̨c im dostęp do możliwości dawanych przez miasto ${ }^{5}$.

Kolejnym, niezwykle istotnym pojęciem jest architektura socjalna. Wiąże się ona przede wszystkim z działaniami mającymi na celu poprawę warunków życia osób, które nie są w stanie same sobie $z$ tą poprawą poradzić. Jest to świadome planowanie i projektowanie przestrzeni społecznej w przestrzeni fizycznej tak, aby zostały zoptymalizowane interakcje międzyludzkie i aby utrzymały się wytworzone wcześniej ramy społeczne. Ponadto architektura socjalna wykorzystuje w procesie projektowania architektonicznego/urbanistycznego doświadczenia płynące z wielu różnych dyscyplin naukowych, m.in. politologii, psychologii, socjologii, ekonomii czy antropologii społecznej i kulturowej ${ }^{6}$. W kontekście slumsów architektura socjalna łączy się z licznymi badaniami nieformalnych aspektów tych obszarów oraz ich związków z relacjami społecznymi. Według jednego z założycieli Urban Think-Tank Alfreda Brillembourga architektura społeczna w nieformalnych miastach wiąże się ze zmianą nastawienia ogólnego myślenia o nich, stworzenia architektury, gdzie architekt staje się moderatorem przestrzeni, w której wysnuwa wizję miasta dynamicznego, cały czas się rozwijającego, a nie statycznego. Chodzi o możliwość zapewnienia marginalizowanej społeczności slumsów równego dostępu do formalnego miasta, poprzez działania związane z modyfikacją istniejącej przestrzeni, tak aby ludzie dalej żyli w swoich społecznościach, tylko że w lepszych warunkach?

\section{PRÓBY ROZWIAZZANIA PROBLEMU NIEFORMALNYCH MIAST}

Jednym z najbardziej problemowych obszarów związanych z niekontrolowanym rozwojem miast nieformalnych jest obszar jednostek miejskich w Ameryce Południowej. Ze względu na sprzyjający klimat oraz dużą dysproporcję pomiędzy najbiedniejszymi i najbogatszymi miasta nieformalne rozrastają się bardzo szybko i adaptują każdy teren. W latach 60 . wiele krajów Ameryki Południowej po licznych nieudanych próbach znalezienia rozwiązania na niekorzystne zmiany w przestrzeni miejskiej przestało inwestować w architekturę socjalną. Wyjątkiem jest peruwiański prezydent-architekt Fernando Belaúnde Terry, który w 1968 roku razem z brytyjskim architektem Peterem Landem próbował, przy pomocy architektów z całego świata, spojrzeć na problem z innej perspektywy. Prezydent zorganizował konkurs na rozwiązanie problemu niekontrolowanego rozrostu nieformalnego miasta. 
Projekt konkursowy został nazwany Proyecto Experimental de Vivienda (PREVI). Założeniem konkursu było zaprojektowanie modelowej dzielnicy na 1500 mieszkań w celu stworzenia prototypów domów elastycznych i mających możliwość rozrastania się w różne strony, tak aby miały szansę przyjąć się w krajach Ameryki Łacińskiej. W konkursie podano kilka głównych warunków: projekty miały pokrywać obszar zabudową o maksymalnej gęstości, koszty wybudowania domów miały być jak najniższe, projekty powinny opierać się na koncepcji rozrastania - tak, aby każdy dom mógł łączyć się z innym lub też rozrastać się w ramach jednej rodziny, domy powinny być odporne na trzęsienie ziemi oraz powinna zostać zachowana skala człowieka i przyjazne, zadbane otoczenie.

Do konkursu zostało zaproszonych 13 architektów z całego świata. Każda z tych osób była zaangażowana już wcześniej w eksperymentalnym projektowaniu budynków socjalnych. $\mathrm{Na}$ przykład James Stirling stworzył Runcorn New Town Housing, Charles Correa był odpowiedzialny za Tube Housing, który okazał się później wzorem dla miasta Gujarat znajdującego się w Indiach, czy też Georges Candilis, twórca Cité Horizontal w Casablance. Na liście finalistów znalazła się również para architektów, którzy reprezentowali Polskę: Oskar Hansen i Svein Hatloy. Prezydent zaprosił też do konkursu 13 lokalnych architektów. W 1969 roku jury wybrało 3 zwycięzców: Metabolistów, Atelier 5 i Herbert Ohl, równocześnie uznając, że powinny zostać wybudowane wszystkie projekty poza dwoma, których koncepcja była za trudna do wykonania ${ }^{8}$. W ciągu 5 lat zostało wybudowanych 500 domów. Projekt dobiegł końca, a jego realizację pozostawiono bez żadnego nadzoru. Uważa się przy tym, że efekty konkursu do tej pory mają bardzo duży wpływ na projektowanie architektury socjalnej, a przede wszystkim na zmianę podejścia architektów do budowania budynków społecznych. PREVI był przykładem bardzo innowacyjnego i eksperymentalnego podejścia do problemu, gdzie łączyła się funkcjonalność z poszukiwaniami granic, tworzonych nie tylko przez ludzi, ale również przez architekturę.

Kolejna inicjatywa była podjęta przez chilijskiego architekta, laureata nagrody Pritzkera w 2016 roku, Alejandra Aravenę. Miała ona na celu rozwiązanie problemu powiększania się nieformalnych miast oraz zagrożenia deprawacji społeczeństwa. Zwycięzca stworzył w 2000 roku akademicką jednostkę badawczą Elemental, w skład której wchodził chilijski koncern energetyczny Copec oraz Pontifical Catholic University of Chile. Jednostka ta postanowiła zająć się problemem slumsów i oddolnie stworzyła rozwiązanie, które zaproponowała później rządowi chilijskiemu. Tworząc na ogromną skalę projekty domów społecznych, skupiała się nie tylko na tym zagadnieniu - patrzono od strony architektury, lecz przede wszystkim przyjęto szerszą perspektywę i rozpoczęto poszukiwania odpowiedzi na pytania, jak można zahamować rozrastające się ubóstwo w nieformalnych miastach oraz jak włączyć zmarginalizowane i niewyedukowane osoby z powrotem do społeczeństwa. Innowacyjnym rozwiązaniem było wprowadzenie na etapie projektowania konsultacji społecznych z ubogimi mieszkańcami Chile w celu opracowania rozwiązania spełniającego również ich wymagania. Pierwszym z wniosków były decyzje o cechach lokalizacji osiedli. Musiały one 
się znaleźć w dogodnym miejscu blisko infrastruktury, a nie na peryferiach, aby lokalne społeczności nie zostały odcięte od źródła zarobków oraz od dobrych wzorców społecznych. Ze względu na trzęsienia ziemi wiele starszych budynków o złej konstrukcji, a dobrej lokalizacji zawalało się, a w ich miejsce można było właśnie zbudować nowe osiedla. Zważając na to, iż mieszkania socjalne w dzisiejszych czasach są budowane bardzo złej jakości, że są małe i niekomfortowe, Alejandro Aravena zaproponował stworzenie domów przyrostowych. System ten polegał na zbudowaniu przez architekta jedynie połowy domu, a drugą połowę mieszkańcy mogliby samodzielnie rozbudować, gdy będą mieli na to fundusze. Zastosował on ideę architektury o strukturze otwartej, w której ludzie dostają wolność w dokończeniu całego projektu, a architekt nie ma wpływu na efekt końcowy, który może być różny. System ten wykorzystuje już wcześniej zastosowane w projekcie PREVI myślenie, w którym ludzie współtworzą architekturę razem z architektem. Pierwszym osiedlem zbudowanym w 2004 roku w ramach projektu grupy Elemental było osiedle Quinta Monroy w Iquique w Północnej części Chile. Budynki były połączone w kwartały dla 25 rodzin z przestrzenią półpubliczną, której nie można było zabudować. Budynki zostały zbudowane z jednorodnej ściany bez ocieplenia. Na ramie konstrukcyjnej, która równocześnie ograniczała zabudowę domu do maksymalnej wielkości $72 \mathrm{~m}^{2}$, wszystko się opierało 9 .

Trochę inaczej do tematu pomocy ludziom w slumsach podeszła grupa Urban Think-Tank (U-TT). Już od 2003 roku jej członkowie starali się poznać specyfikę miasta nieformalnego w Caracas, tak aby nie wprowadzać żadnych narzuconych na siłę form budynków, tylko wpisać się w istniejącą architekturę. Pierwszymi ich projektami było wykorzystanie martwej przestrzeni miasta, np. niewykorzystane miejsce pod wiaduktem przerobili na dom dla bezdomnych, a miejsce, w którym znajdowało się boisko do piłki nożnej, zmienili na 7-piętrowy wertykalny budynek gimnastyczny z boiskiem na dachu. W środku umieścili między innymi boisko sportowe, bieżnię, ściankę wspinaczkową oraz szatnie. Zbudowana infrastruktura sportowa miała za zadanie wprowadzić azyl bezpieczeństwa dla dzieci z dzielnicy Chacao, która znajdowała się ciągle na linii ostrzału wojen gangów ${ }^{10}$. Projekt ten był jednym z pierwszych mających na celu poradzenie sobie z problemem jednego z państw w Ameryce Południowej z największym odsetkiem ludzi mieszkających w slumsach ${ }^{11}$.

Innym bardzo dużym projektem tej grupy było zbudowanie kolejki linowej Metrocable łączącej największą stację metra ze wzgórzem San Augustin - jednym z największych slumsów w Caracas. Po wymyśleniu idei stacji grupa U-TT podjęła sześciomiesięczną inicjatywę analityczno-planistyczną, angażując do współpracy austriackiego producenta kolei linowych Doppelmayr, inżynierów ds. klimatu Transolar i amerykańską cywilną firmę budowlaną Silman \& Associates. W czasie konsultacji społecznych samorząd chciał zbudować drogę łączącą wzgórze z centrum, wyburzając przy tym $1 / 3$ domów na zboczu. Sprzeciwili się temu w znacznym stopniu mieszkańcy, wykazując się bardzo dużym zainteresowaniem i pokazując, że są bardzo dobrze poinformowani o planie kolejki. Ostatecznie w projekcie znajduje się w sumie pięć stacji rozsianych po całym wzgórzu. Każda z nich posiada wspólny podstawowy 
zestaw komponentów takich jak platformy, rampy dostępu, system cyrkulacji czy konstrukcję, ale też każda z nich ma trochę inną konfigurację dodatkowych funkcji. Jedne posiadają funkcje administracyjne i kulturalne, inne społeczne czy mieszkaniowe, a jeszcze inne pełnią rolę zbiornika na wodę, która może zostać wykorzystana przez okolicznych mieszkańców. Każda ze stacji ma zaprojektowane dodatkowe funkcje, jednakże nie wszystkie funkcje zostaną zrealizowane od razu. Cały system jest zrobiony z elementów prefabrykowanych, łatwo montowalnych. Stacje ze względu na obszary sejsmiczne są zbudowane na stalowych słupach. Stacje kolejek z wyjątkiem prądu dostarczanego do systemu kablowego ze źródła komunalnego mają być samowystarczalne i niezależne od energii. Stacje i konstrukcje sąsiednie nie wymagają żadnych mechanicznych urządzeń HVAC. Każda stacja jest zaprojektowana tak, aby zawierała „łapacz wiatru”, który kieruje dominującą bryzę do wnętrza12. Projekt ten przyczynił się do integracji części miasta nieformalnego z formalnym, jednakże nie spowodował zupełnego wciągnięcia i zlikwidowania miasta nieformalnego.

\section{PODSUMOWANIE}

Na przestrzeni ostatnich lat pojawiło się kilka propozycji rozwiązania problemu dotyczącego powiększającej się liczby ludności mieszkającej w slumsach i braku wystarczającej ilości mieszkań. Problem slumsów mający swoje źródła w zwiększającej się dysproporcji pomiędzy najbiedniejszymi i najbogatszymi mieszkańcami miast generuje bardzo wiele negatywnych skutków. Między innymi następuje marginalizacja ubogich mieszkańców, odcięcie ich od możliwości zatrudnienia czy też zwiększenie ryzyka powstawania wielu chorób i epidemii. Warto zwrócić uwagę, że architektom próbującym rozwiązywać tego typu problemy nie wystarczy myślenie w kategoriach dobrego projektu, bardzo często projektant musi uwzględnić kontekst społeczny, politykę, psychologię czy finanse. Nie ma też jednej sprawdzonej zunifikowanej metody tworzenia projektu, funkcjonującego w każdym miejscu na Ziemi. Wszystkie problemowe obszary należy dobrze przeanalizować, tak żeby rozwiązanie nie kolidowało z wartościami kulturowymi czy też relacjami pomiędzy danymi społecznościami. Jak wspominał w swojej wypowiedzi Alfredo Brillembourg, jeden z założycieli U-TT, w dzisiejszych czasach potrzebujemy innego typu architekta - moderatora przestrzeni, który weźmie pod uwagę, że miasto jest jednostką dynamiczną, a nie statyczną, i że miasta są dla ludzi i społeczności ${ }^{13}$. 


\section{PRZYPISY}

1 United Nations Human Settlements Programme (UN-HABITAT), https://unhabitat.org.

2 Ministerstwo Rodziny, Pracy i Polityki Społecznej, https://www.gov.pl/web/rodzina/ przeciwdzialanie-ubostwu-w-polsce.

3 The Plan Journal, http://www.theplanjournal.com/article/how-does-work-shape-informal-cities-critical-design-cities-and-housing-brazilian-slums.

4 United Nations Human Settlements Programme (UN-HABITAT), https://unhabitat.org/ books/slums-of-the-world-the-face-of-urban-poverty-in-the-new-millennium/.

5 J. McGuirk, Radykalne miasta. Przez Amerykę Łacińskq w poszukiwaniu nowej architektury, Fundacja Bęc Zmiana Respublica, Warszawa 2015, s. 42.

6 HuffPost, https://www.huffpost.com/entry/social-architecture-a-new_b_5448130.

7 TEDxLakeGeneva, The growing informal city: Alfredo Brillembourg, https://www.youtube. com/watch?v=UJXtOOP4WQE.

8 Architectuul, http://architectuul.com/architecture/previ.

9 Elemental, Incremental housing and participatory design manual, red. A. Aravena, A. lacobelli, Cantz Hantje, Włochy 2016.

10 Urban-matters, http://urban-matters.org/projectsbyindividuals/vertical-gymnasium.

11 J. McGuirk, op. cit., s. 148.

12 Singhal Sumit, https://www10.aeccafe.com/blogs/arch-showcase/2013/10/19/metrocable-in-caracas-venezuela-by-urban-think-tank/.

13 TEDxLakeGeneva, op. cit.

\section{BIBLIOGRAFIA}

Architectuul, [online] http://architectuul.com/architecture/previ (dostęp: 27.01.2019).

Elemental, Incremental housing and participatory design manual, red. A. Aravena, A. Iacobelli, Cantz Hantje, Włochy 2016.

HuffPost, [online] https://www.huffpost.com/entry/social-architecture-a-new_b_5448130 (dostęp: 30.01.2019).

Magazyn.o, [online] http://magazyn.o.pl/2016/katarzyna-zahorska-nowoczesne-osiedla-dla-nowoczesnego-spoleczenstwa/\#/ (dostęp: 27.01.2019).

McGuirk J., Radykalne miasta. Przez Amerykę Łacińskq w poszukiwaniu nowej architektury, Fundacja Bęc Zmiana - Fundacja Res Publica, Warszawa 2015.

Ministerstwo Rodziny, Pracy i Polityki Społecznej, [online] https://www.gov.pl/web/rodzina/ przeciwdzialanie-ubostwu-w-polsce (dostęp: 31.01.2019).

Singhal Sumit, [online] https://www10.aeccafe.com/blogs/arch-showcase/2013/10/19/ metro-cable-in-caracas-venezuela-by-urban-think-tank/ (dostęp: 31.01.2019). 
TEDx Talks, The growing informal city: Alfredo Brillembourg at TEDxLakeGeneva, [online] https://www.youtube.com/watch?v=UJXtOOP4WQE (dostęp: 27.01.2019).

The Plan Journal, [online] http://www.theplanjournal.com/article/how-does-work-shape-informal-cities-critical-design-cities-and-housing-brazilian-slums (dostęp: 27.01.2019).

United Nations Human Settlements Programme (UN-HABITAT), [online] https://unhabitat. org/books/slums-of-the-world-the-face-of-urban-poverty-in-the-new-millennium/ (dostęp: 30.01.2019).

United Nations Human Settlements Programme (UN-HABITAT), [online] https://unhabitat. org/books/state-of-the-worlds-cities-20102011-cities-for-all-bridging-the-urban-divide/ (dostęp: 30.01.2019).

Urban-matters, [online] http://urban-matters.org/projectsbyindividuals/vertical-gymnasium (dostęp: 31.01.2019). 